\title{
地域づくりに対する能動的な参画態度の形成 に関する計画的研究
}

A study on the formation of attitude toward participation in the community development

\author{
山田和臣*，藍澤 宏**，斎藤亮司*
}

Kazuomi YAMADA*, Hiroshi AIZAWA**, Ryoji SAITO*

*東京工業大学大学院, **東京工業大学文教施設研究關発センター

-Tokyo Institute of Technology, * *Research and Development Center for Educational Facilities, Tokyo Institute of Technology

\section{I はじめに}

\section{1. 研究の背景と目的}

地域住民のためのより良い生活の場を創造しよ うとする地域づくりは，住民自らが自分たちの地 域社会を形づくるという住民自治の理念に基づき， これまでの行政主導によるものから住民主導のも のへと移行しつつある。そのため, 住民の主体的 な参画を得る必要性が一層增してきている。

これまでにも，地域づくりへの住民参画を扱つ た研究は, 数多く"1なされてきた。しかしなが らこれらの研究の多くは，住民が主体的に参画で きる，地域づくりのプロセスを明らかにするとい う視点に立っているが, 住民各人に, 地域づくり に対する能動的な参画態度を根付かせることも必 要であるという視点に立ち，その参画態度のかた ちづくられかたをとらえた研究は，数が少ない。

そこで本研究では，住民主導の地域づくりに対 する, 人々の参画態度形成の仕組みをとらえ, 能 動的な参画態度の形成要因とその構造を明らかに することにより，住民の主体的な参画を酲成する ための方法を導き出すことを目的とする。

2. 研究の方法

まず，本研究において用いる「地域づくり」と いう用語の定義を行う。「地域」の篹囲は, 従来か ら住民にとって最も身近な地域社会である「集落」 をとる。そして，「地域づくり」を実践するには， 集落に賦存している地域資源生 ${ }^{2)}$ を適切に維持 -
保全する中で，住民の能動的な計画への参画を促 していくことが必要条件となる。つまり, 本稿に おける「地域づくり」とは,「集落社会を活性化す るための地域資源の有効的な活用方法」を求める こととする。

次に, 参画態度形成の仕組みを以下のように考 え、人々の参画態度の形成を把握する（図 1)。

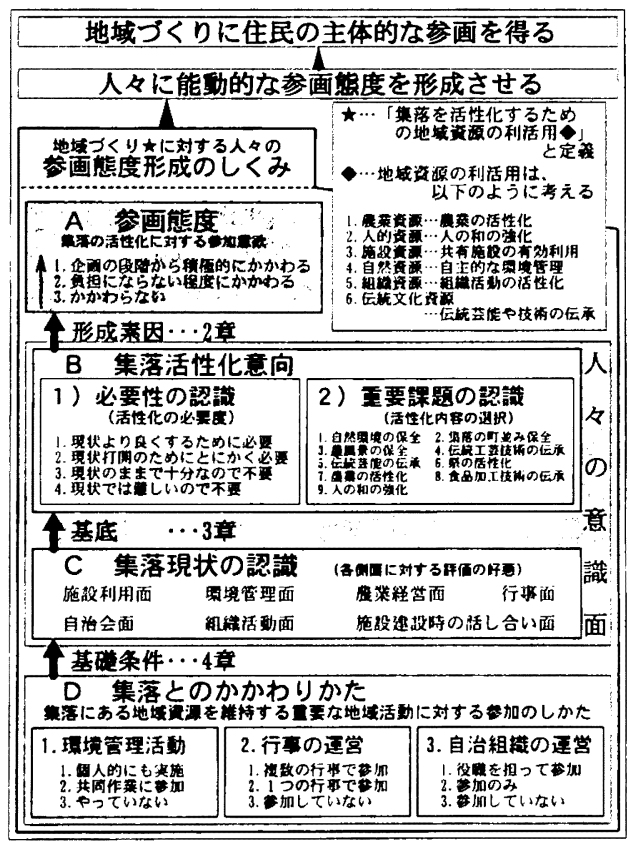

図1 研究の概念図 
第1に, 図1中のAの地域づくりに対する住民 の参画態度として, 能動的なもの(「企画の段階か ら積極的にかかわる」)，消極的なもの（「かかわら ない」)，両者の中間（「負担にならない程度にかか わる」)，以上 3 つの尺度により，参画態度の能動 性を把握する。

第 2 に， B の参画態度の形成素因としては，ま ず，住民が集落活性化に対する必要性の認識を， 集落活性化に対する必要/不要の判断（必要性の 認識) により捉え, 次に, 集落の活性化素材とし て, 利活用すべき地域資源の認識内容（重要課題 の認識)を明らかにする。

第 3 に, C の住民の集落活性化に対する意向や 参画姿勢に影響を与える条件として, 住民の集落 の現状（環境管理活動, 組織運営, 行事運営, 農 業経営等の側面に対する, 集落住民の対応状況） に対する評価の特徵を捉える。

第 4 に, D の集落現状の認識を左右する基礎条 件として, 住民の地域活動における参加状況やか かわり方について把握する。その地域活動の内容 は, 環境管理活動, 行事の運営, 自治組織の運営, の以上 3 つである。

以上のように想定した，住民の「地域づくり」 に対する参画態度形成の仕組みを捉えるためのデ 一夕は，住民に対するアンケート調査により収集 した（表 1)。調查集落は, 1998 年度に青森県十和 田三戸地域の全 305 集落を対象にした「地域資源 の賦存状況注3)」に関する調查結果をもとに，地域 資源を利活用した住民活動に糟極的な姿势を示す 3 つの集落を選定した。調查用紙の配布, 回収方 法及びサンプル数等については表 1 に示す。

表 1 調查の概要

\begin{tabular}{|c|c|}
\hline 1. 闌查刘象地 & 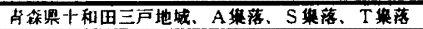 \\
\hline 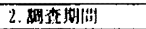 & 1999 年 11 月 \\
\hline 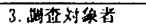 & 中学生以上の捗落居住者 \\
\hline 4.欺存方法 & 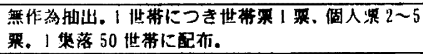 \\
\hline 5. 有·回収笨数 & 450 然配布 362 買回収 \\
\hline 6. 回収力法 & 回収员 3 名て各集落各世带に勃問。 \\
\hline 7. 有勃覥妄 & 319 眯 \\
\hline 8. 苔勃赫の内识 & 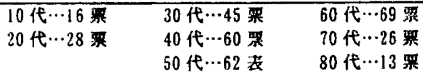 \\
\hline 9. 赒查内容 & 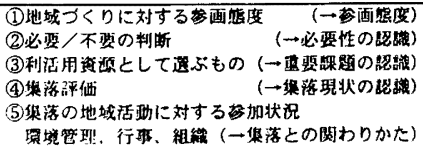 \\
\hline
\end{tabular}

\section{II 集落活性化意向と参画態度}

\section{1. 地域づくりに対する参画態度}

年代別に見ると， 10 代では, 能動的な参画態度 の人と消極的な参画態度の人に大きく分かれてい る(図 2)。20５0 代においては中間的な参画態度 の人が最も多く, 60〜80 代では消極的な参画態度 の人が多い。このように, 20〜 50 代では多くの人 が関わろうという態度を示していることが確認さ れる。以下では，サンプル数を考虑し， 10〜20 代の若者層, 30 50 代の中年層, $60 \sim 80$ 代の高齢 層という， 3 つの年齢層に分けて見ていく。

2. 必要性の認識と参画態度の関係

参画態度の形成素因と想定した必要性の認識は, 「現状をより良くするために必要」という人が, どの年齢層でも最も多くなっている（図 3)。

次に, 参画態度との対応を見る (図 4)。ただし， グラフの維軸は, 参画態度の 1.「企画から積極的 にかかわる」に1点，2．「負担にならない程度に かかわる」に 0 点, 3.「かかわらない」に-1点を 与えた時の, 参画態度の加重平均值を表す。これ より，必要性を認識することで，能動的な参画態 度を示すことが確かめられる。また，不要と考え

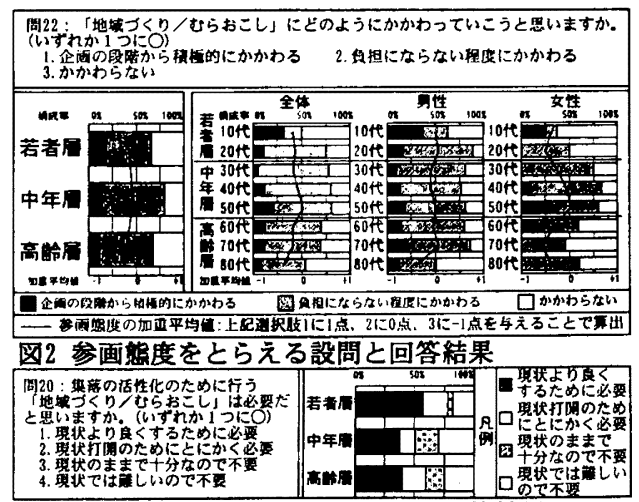

図3必要性の哂謤をとらえる設問と回答結果

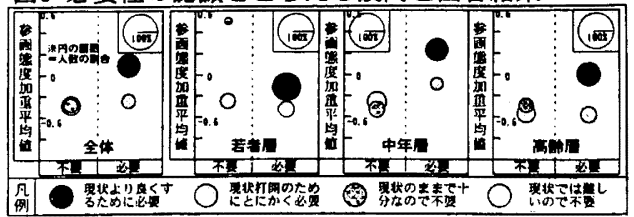

図4 必要性の認識別にみた参画態度の加重平均值 
るなかでも、「現状のままで十分」と認識する人は,

「現状では難しい」と認識する人よりも，能動的 な参画態度を示す。つまり，現状に良い評価を示 すことも重要であることが言え，集落現状の認識 が参画態度に影辢することが明らかになった。

3. 重要課題の認識と参画態度の関倸

まず，地域づくりにおける重要課題に対する認 識をとらえるために，図 5 に示す調査項目に対す る回答をもとに，集落活性化においてなすべき内 容としての利活用資源の選びかたを見る。まず， 図に示す指標により，数量化而類を用いて多变量 解析を行った（図 5)。これにより得られた主要な

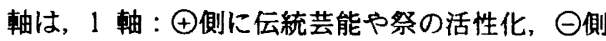
に農風景の保全や農業経営の奇与により, 活動の 内容の文化的側面一経済的側面を表す軸, 2 軸: $\oplus$ 側に食品加工や工芸の技術伝承，側に自然䁵境 保全の寄与により，技術を要するもの一睘境整備 面という取り組みたいものの性質を表す軸, 3 軸 : ๑側に人の和の強化, $\ominus$ 側に自然㭚境保全の 寄与により, 計画課題となりにくいもの一なりや すいものを表す軸, であると理解する。次に, こ の分析で得られた各軸のサンプル得点値によりク ラスター分析を行った。結果として, 重要課題の 認識は，（I）自然環境や農の風景の保全を重視す る人，（II）農業の活性化を重視する人，（III）人 の和の強化を重視する人，(IV) 伝統技術の伝承を 重視する人，(V) 祭の活性化を重視する人，(VI) 重視するものがない人の, 計 6 類型に分けられた。

次に, 得られた類型と参画態度との対応を見る (図 6)。グラフの縦軸は図 5 と同様に参画態度の 加重平均値を示し, 横軸は, 類型を求める際に使 用した調查項目の回答において，選んだ選択肢の 数の平均值を示す。これにより，地域づくりにお いて注目する事柄の多さや参画態度が, 重要課題 の認識とかかわりがあることを見ることができる。 結果として, 伝統技術の伝承を重視する (IV) は, どの年齢層においても，注目する事柄が多く，参 画態度が高いことが明らかになった。注目する事 柄が多い人ほど参画態度が能動的であることから も,伝統技術の伝承を重要課題と認識することは, 能動的な参画態度を形成する有効な要因であると 考えられる。

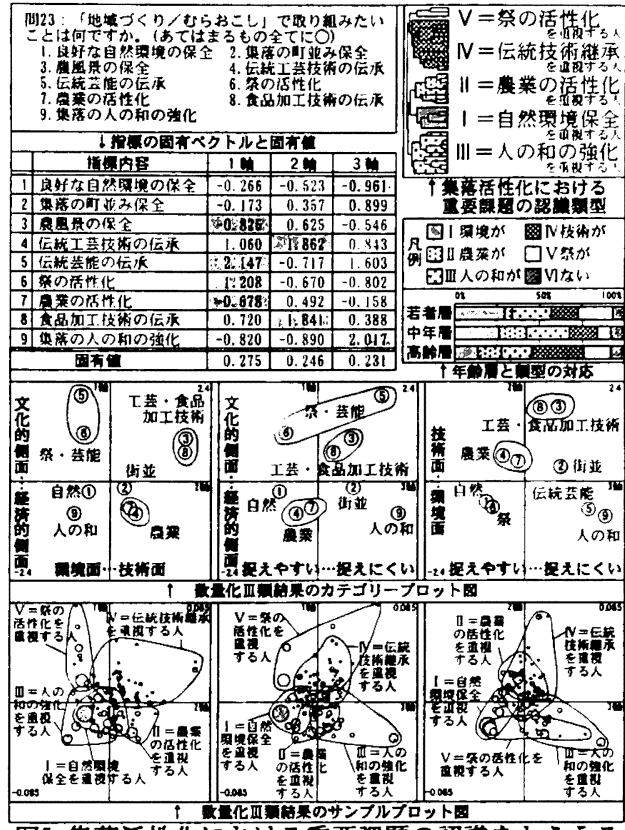

図5 集落活性化における重要課題の認識をとらえる 設問と人の類型化

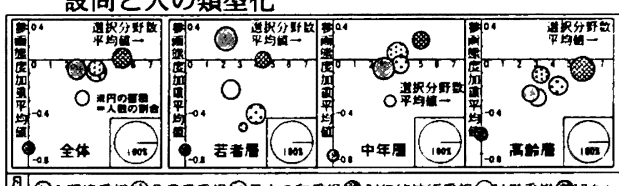

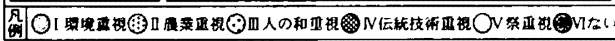
図6 重要課題の認識類型別 参画䑨度加重平均値

\section{III 集落現状の認識と参画態度}

1. 集落現状の認識からみた住民の類型化

人々の，集落現状の認識のしかたを把握するた めに, 図 7 に示す 25 指標を用いて主成分分析を行 つた（図 7)。結果として得られた主たる成分は, 1 軸: 現状評価の好悪を表す軸, 2 軸 : $\oplus$ 側に組織 活動や伝統行事活動面, ○側に生活環境の維持管 理面の評価項目が寄与する軸, 3 軸 : $\bigoplus$ 側に共有 施設の利用や環境管理面, ○側に農業経営や施設 建設時の話し合い面での評価項目が寄与する軸, となる。これを更に詳しく見ることにより，(1) 環境管理面，(2）組織・行事の運営面，(3) 施設 建設・㖘業経営面, という 3 側面から, 集落の現 
状が認識されるととらえ られる。

次に, この分析により 得られた主たる 3 つの軸 に対するサンプル得点値 から, クラスター分析に より類型化を行った。そ の結果, A : 全ての側面で 良いと認識する人, C: 全 ての側面で悪いと認識す る人, B: A と C の中間に 位置する人，が抽出され， 更にBは，B1：組織・行 事の運営面で認識が低い 人, B2：環境管理面で認 識が低い人, B3：施設建 設・農業経営面で訫識が 低い人,の 3 つに分けら れ, 計 5 類型が得られた。 2. 集落現状の認識の類型 と参画態度との関倸

得られた 5 つの類型と 参画態度との対応を見る と, 集落の現状に対して 良い認識を示す人ほど, 能動的な参画態度を示し ている(図 8)。また, B のなかで比べると, 若者 層は $\mathrm{B} 1$ ，中年層は $\mathrm{B} 2$, 高 踰層は B3 が、消極的な参 画態度を示すことから，

若者層においては組織・行事の運営面で, 中年層 においては瑾境管理面で, 高龈層では施設建設・ 農業経営面で, 現状を良いと認識できることが, 能動的な参画態度の形成に必要な条件となる。 3. 地域づくりの必要性の認識との関係

地域づくりの必要性に対する認識との対応を見 る(図 9)。ここでも集落現状に対して良い認識を 示す人ほど, 地域づくりの必要性を認識する人が 多い。また, その必要性の判断で現状を好評価し た「現状をより良くするために必要」、「現状で十 分なので不要」という考え方の人も, 集落現状の

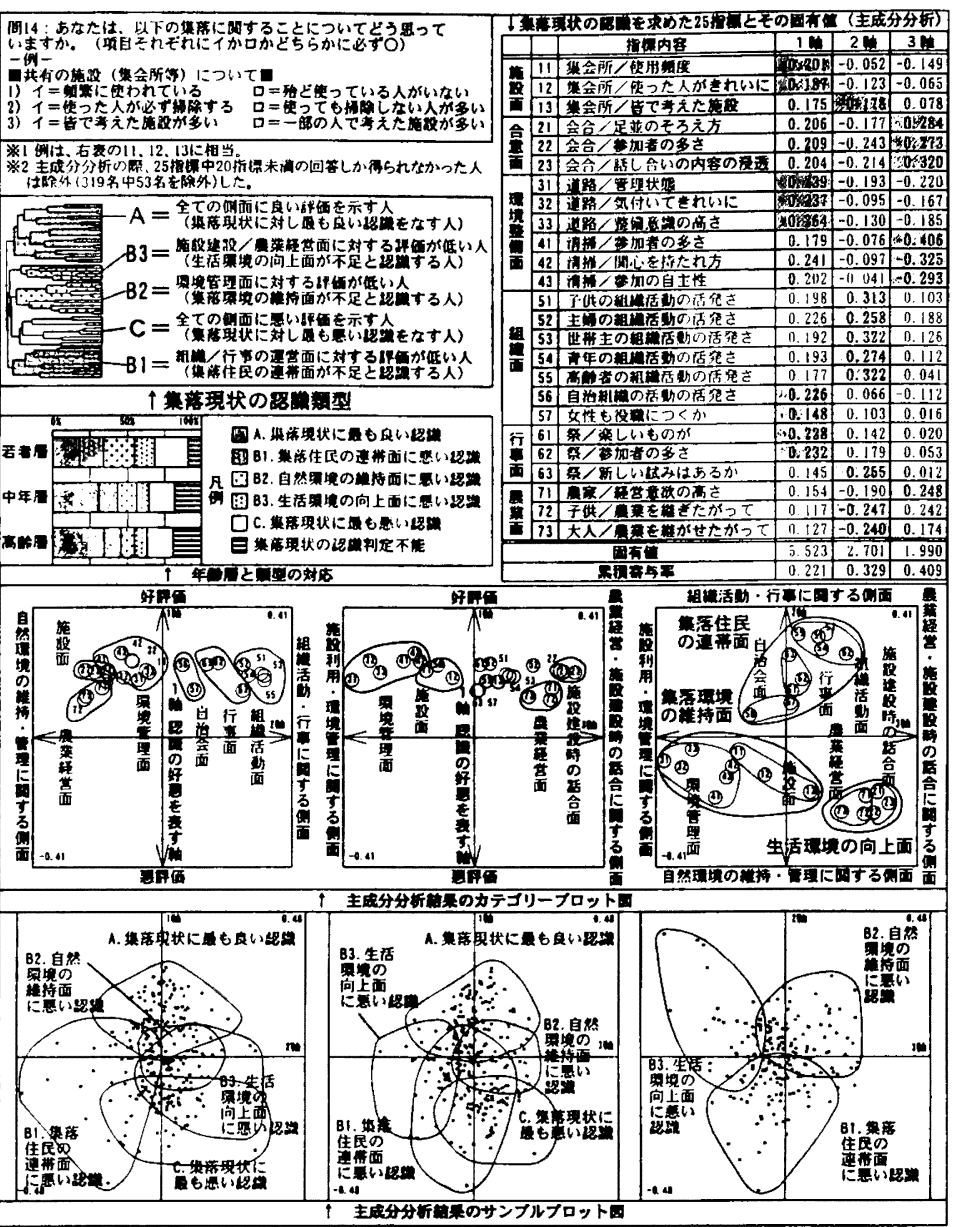

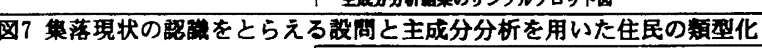

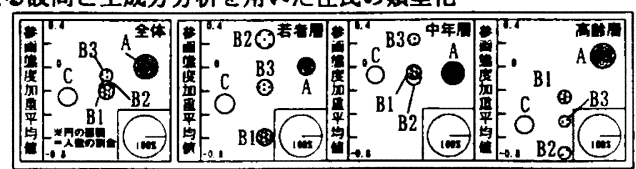

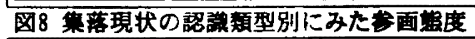

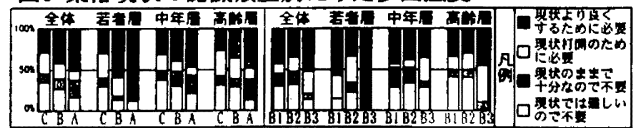

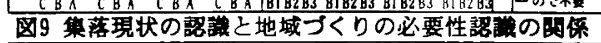

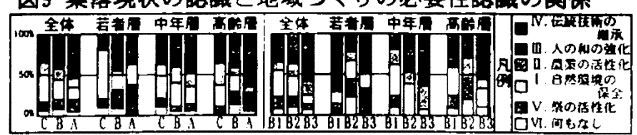

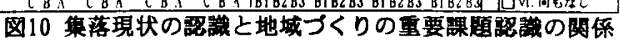


認識が良い人ほど多くなる。このように，集落現 状に対する良い認識が，地域づくりの必要性認識 につながり，能動的な参画態度を形成することが 明らかになった。また，B のなかで比べると，ど の年齢層においても，B3 には必要性を認識する人 が多く，中年層と高齢層で見たとき，B1，B2 には 現状を良いと判断する人が多い。これより，どの 側面を良いと認識するかによって，必要性の認識 が異なることが明らかになった。

4. 地域づくりの重要課題の認識類型との関係

集落現状に対して良い認識を示す人は，伝統技 術や人の和, 祭を重要視しており，逆に悪い認識 を示す人は，䍗境保全を重要視している(図 10)。 これらの結果から,集落現状に対する良い認識は, 能動的な参画態度を形成しやすい重要課題の認識 につながることが明らかになった。また B のなか で比べると，B3 は，年齢層の違いに関わらず，人 の和を重視することが言える。また B1 は，環境保 全を重視する人が多い。これより，集落現状のあ る側面に対する良い認識は, その側面に対する自 信を促し，関連した地域资源の利活用を考えるこ とにつながることが明らかになった。

以上から, 集落現状の認識を良い方向に導くこ とが，住民にとって集落に対する自信を生み出し， 人々の能動的な参画態度を形成することにもつな かっっいると考えられる。

\section{IV 集落との関わりかたと参画態度}

1. 地域活動に対する人々の参加のしかた

参画態度形成の基礎条件として考えた人々の集 落との関わりかたを, 集落の地域資源を維持する ための重要な活動である(1)環境管理活動(2)行事の 運営(3)自治組織の運営, の3 つの活動に対する, 人々の参加のしかたにより把握する（図 11）。年 路首別に見ると，若者層はほとんどそれらの活動 に参加しておらず，中高年層が地域活動の役割を 持っていることが確認できる。

2. 集落との関わりかたとの対応

次に, 集落現状の認識類型ごとに, 地域活動に 対する参加状況を見る（図 12）。グラフの縦軸は
参画態度の加重平均値を表し，横軸はそれぞれの 地域活動に対し，最も積極的に参加しているもの に 1 点, 最も消極的なものに- 1 点, 中間に 0 点を 与えたときの, 積極性の加重平均値で表したもの である。このグラフから, どの年齢層でも能動的 な参画態度を示した $\mathrm{A}$ タイプの人は, どの地域活 動に対しても梁く関わっている。特に，若者層で は行事の運営, 高齢首では自治組織の運営に対し て，顕著である。B タイプを詳しく見ると，若者 層においては B2 が行事の運営, B3 が自治組織の 運営に, 特に深く関わっており, 高龄層において は B1 が環境管理活動，B3 が行事の運営に，特に 深く関わっている。

結果として, 中高年層では, 地域活動に対して 積極的に関わる人ほど集落現状の認識も良くなり， 能動的な参画態度に結びつくことが明らかになっ た。しかしながら若者層では, 地域活動に対して 積極的に関わるほど集落現状の認識が良くなると は言い切れず，地域活動に対する参加のしかたを 見直すことが，必ずしも能動的な参画態度の形成 に有効に㗢くとは限らないことが明らかになった。

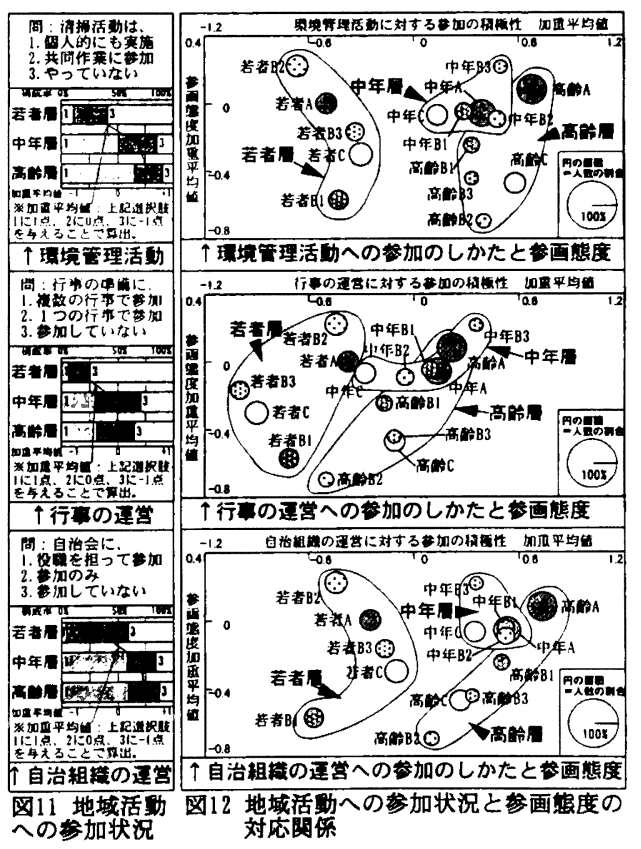




\section{$\mathrm{V}$ おわりに}

以上の研究成果として，地域づくりに対する住 民の参画態度形成の特徵を，以下の様に整理する。

(1)集落現状に対する良い認識は, 能動的な参画 態度の形成に奇与することが得られた。すなわち， 人々の集落現状に対し，積極的に評価させること により, 能動的な参画態度を育成することが可能 になる。

(2)集落現状に対する認識のしかたは，集落住民 の連帯感があらわれる組織・行事の運営の側面, 生活環境の向上につながる施設建設・農業経営の 側面, 集落畩境を維持するための環境管理の側面, の 3 つの分野からなる三極構造により構成される ことが明らかになった。その各側面を活かした地 域づくりに住民を参画させることは，住民の主体 的な参画姿勢を引き出しやすくする条件となる。

(3)環境管理等の集落の地域資源を維持する諸活 動への参加のしかたと集落現状に対する住民評価 とは関倸性が強いことが求められた。したがって, 現行の地域活動に対し積極的に住民を関わらせる ことが集落の現状を正確に認識する上で重要なこ ととなる。

(4)中年層や高齢層では，地域活動への積極的な 参加が集落現状に対する良い認識につながり, 能 動的な参画態度を形成するという構造が見られた。 しかし，若者層に関しては，集落現状に対する良 い認識が, 必ずしも能動的な参画態度には結びつ いていない。現状では，若者層が集落の地域活動 に関わる機会が少なく，中高年層で見られるよう な集落との関わりかたを，能動的に作り出すこと が必要である。今後は，若者層において集落と関 わる機会を增やすことが，地域づくりに若者の参 画を得るための基礎条件となる。
【注釈】

注 1)（1)星野敏（1999）：集落行事・生活習惯の見直しに関 する計画論的研究，1999 年度農村計画論文集, pp. 211-216, (2)佐藤洋平ら (2000): 協働型地域づくりに おける社会集団代表方式の有效性之課題, 2000 年度曹 村計画論文集, pp.91-96，(3)三橋伸夫ら (1995)：農村集 落における活動計画づくりの展開と課題一新潟県小国 町における事例的研究, 平成 7 年度都市計画論文集, No30, pp. $361-366$

注 2）(1)蓝澤宏ほか (1996)：集落立地類型からみた地域资 源樰造之集落誘導の方向性一農村地域における地域資源 からみた集落誘道に関する研究 その 1 ，日本建築学会 論文報告集. №484, pp.137-146 (2)藍澤宏ほか(1998)： 一般集落と推集落との相连からみた地域資源による 集落誘導一農村地域における地域資源からみた集落誘導 に関する研究 その2, 日本建築学会論文報告集, №507, pp.143-149 (3)藍澤宏ほか (1999): 中山間地域における 居住者の地域資源評価からみた集落の誘尊要件 農村地 域における地域資源からみた集落誘導に関する研究 そ の3，日本建築学会諭文報告集，№518，pp. 197-203 (4) 石川宏之ほか(2000) : 地域資源に対する川㱦市民の保全 意識の形成に関する調查研究, 日本建築学会技術報告集, No. 1456, pp. 203-208

注 3）藍澤宏ほか(2001)：農村地域における地域資源の賦 存状況からみた資源分布構造に関する研究, 日本建築学 会論文報告集，№548，pp. 145-152 【参考文献】

1) 佐藤洋平ほか (2000)：山間農業集落における農業・農村 基盤の維持·管理, 2000 年度農村計画論文集, pp. 259-264

2) 藤居良夫 (2000): 中山間地域集落における地域特性と住 民意識との関連に関する考察, 2000 年度農村計画論文 集. pp. 265-300

3) 小田切德美, 植田和弘ほか (2000) : 自然 - 経済 - 人が好 循琵する中山間地域，NIRA 政策研究 2000, Vol.13 Nol

\footnotetext{
Recently, it is claimed that we have to gain resident's participation in the community development. Then, we studied on how a person forms his attitude toward participation in his settlement's community development, and how to make it positive. As a result, his attitude toward participation is influenced by his intention of developing his settlement, which is deeply influenced by his recognition of the present condition of his settlement. And, the last one is almost influenced by his experience in taking part in community management. In conclusion, it is important to consider how to make young people, who have a little experience in joining community management, have several parts in it.
} 